\title{
Political Risks and Japanese Foreign Direct Investment in East Asia: A Case Study of "China-Plus-One"
}

\author{
Keisuke Iida
}

\begin{abstract}
The East Asian political situation has grown volatile as a result of territorial disputes, historical legacies, and other regional rivalries. On the other hand, another notable phenomenon among East Asian countries is a very high degree of economic interdependence. To understand these somewhat contradictory phenomena - and, in particular, how private actors have engaged in cross-border economic activities to cope with political instability - this study will examine the China-plus-one diversification strategy that has been adopted by some Japanese multinationals. This study finds that an increasing number of Japanese firms already employ this strategy, or are considering its use; it also finds that the impact of anti-Japanese protests against Japanese firms in China is increasing, and that the most highly preferred investment destination in terms of diversification is Southeast Asia.
\end{abstract}

Key Words: political risk, foreign direct investment, portfolio diversification, Sino-Japanese relations

$\mathrm{T}$ he relationship between diplomatic relations and economics in East Asia is a complex one. During the early 2000s, the relationship between Japan and China was characterized as "cold politics, hot economics" (Seirei Keinetsu), because economic ties were increasing rapidly, despite strong antagonism at the political level - antagonism largely due to Japanese Prime Minister Junichiro Koizumi's repeated visits to the Yasukuni Shrine. However, in recent years, the relationship has turned into "cold politics, cool economics" (Seirei Keiryou) and is even at risk of becoming "cold politics, cold economics" (SeikeiReirei).

On the other hand, the data show that Japan - China trade increased between 2012 and 2013, albeit more slowly than previously, despite crises in bilateral relations. Additionally, the number of tourists from China to Japan, which dropped between 2012 and 2013, sharply rebounded before the bilateral relationship

*Keisuke Iida (iida@j.u-tokyo.ac.jp) is Professor in the Graduate Schools for Law and Politics at the University of Tokyo. He holds a Ph.D. from Harvard University and has formerly taught at Princeton University and Aoyama Gakuin University. His major publications include Legalization and Japan: The Politics of WTO Dispute Settlement(2006) and International Monetary Cooperation among the United States, Japan, and Germany(1999). His current research interests include the economy-security nexus in East Asia, the politics of trade, and the political economy of financial and currency crises.

The Korean J ournal of International Studies Vol.13-2 (August 2015), 383-410. http://dx.doi.org/10.14731/kjis.2015.08.13.2.383

(c) 2015 The Korean Association of International Studies 
improved. Therefore, it is important to understand whether there is a systematic (or predictable) relationship in East Asia between political or diplomatic relations on one hand and economic exchange on the other. Is the correlation negative, zero, or positive?

The relationship between politics and economics in East Asia has been sporadically studied for some time. For example, Pempel (2013) assembled a group of scholars to examine this relationship, and they found many complexities. While Iida (2013) found some spillover from economic cooperation to security cooperation in the early 2000 s among China, Japan, and South Korea, others found no such relationship.

Davis and Meunier (2011) found no systematic impact of political tension on trade and investment; Davis et al. (2014), however, found that conflict impacts trade in the state-owned sector. The latter finding implies that economic activities by private-sector actors are somehow immune to political conflict.

There is ample episodic evidence, however, that political tensions impact economics; a most memorable example relates to the embargo of rare earths. Prior to the Senkaku Islands crisis in 2010, Japan depended on China to supply over 90 percent of these elements; however, after the crisis - in which a Chinese fishing boat collided with the Japanese Coast Guard near the Senkaku Islands and Japanese law enforcement authorities detained the boat captain, in September 2010 - China retaliated by halting its export of rare earths to Japan. It was only after the captain was released that China resumed the export of rare earths. After this incident, the Japanese government and industries decided to diversify the country's rare earths supply, away from China; it instead looked to Australia, India, Kazakhstan, Mongolia, and Vietnam (Kumagai 2013). Dependence on China in this area is now one-half of what it was before the crisis. The fallout from this incident clearly demonstrates that political conflict reduces economic interdependence in East Asia, even though it is confined to a handful of industrial materials.

This conflict has had another outcome, producing in Japan the phenomenon known as "China-plus-one." In the 1990s and 2000s, Japanese corporations made enormous amounts of foreign direct investment (FDI) in China; these significantly increased after 2001, when China became a member of the World Trade Organization (WTO). It is now rare to find a large Japanese corporation that does not have a manufacturing operation in China. However, after the 2010 Senkaku (Diaoyu) crisis, and especially after the Japanese nationalization of the Senkaku Islands in 2012, the bilateral relationship between Japan and China hit a new low. In addition, Chinese labor costs have increased, reducing the attractiveness of investment in China. Consequently, Japanese corporations have begun to see the 
high risk inherent in investing solely in China, and it so has become fashionable for Japanese firms to diversify foreign investment away from China. This Chinaplus-one strategy therefore refers to the addition of another investment destination to a business portfolio.

The remainder of this article is organized as follows. The section entitled "Theory" discusses the relevant International Relations (IR) Theory and provides a review of the literature on political risks and FDI in management studies. After introducing the concept of China-plus-one, the following section entitled "Trends in Japanese Foreign Direct Investment" measures the dependent variable on the aggregate level. The section "China Risks" describes the independent variable of the article - namely, political and nonpolitical risks that are driving the phenomenon of China-plus-one. Note that there are two parts to China-plus-one - the first part being a slowdown or decrease in Japanese FDI in China and the second being an increase in Japanese FDI in Southeast Asian and South Asian countries. The following section ("Plus-one Countries") describes this second part. The article adds two more additional analyses: the first examines firm-level motivations about China-plus-one to see whether the presumed motivation of diversification operates at the micro level; the second, a brief section on American FDI, is added to see if we can isolate the impact of political risks from the other factors, since the United States has not had as many political frictions with China in the relevant period as Japan. It turns out that economic factors are enough to drive American FDI away from China.

\section{THEORY}

\section{A GAP IN INTERNATIONAL RELATIONS THEORY}

Although these episodic examples are taken from recent East Asian history, they are highly consistent with existing international relations theory. There are two classes of theory. In one, politics is posited as an independent variable, with economic interdependence acting only as a dependent variable; in the other, the causal relationship runs in the other direction. This study will concentrate primarily on the first class of theory.

Realist theories tend to take power politics as a determinant factor in international relations. Realists consider a state's highest goal to be survival, and security crises that threaten state survival or sovereignty are thought to be the highest priorities for state policy-makers. In this view, policy-makers are willing to sacrifice other goals - such as economic welfare - to ensure survival. This leads to what is known as "economic statecraft," where economic means are used to 
advance national security or political interests (Baldwin 1985).

Economic sanctions are the most common economic instrument at the state's disposal in pursuing economic statecraft. Economic sanctions reduce economic interdependence in both the short and long term. In the short term, economic interdependence is reduced because economic sanctions often involve a trade embargo, or cuts in foreign aid. Either way, sanctions reduce economic interdependence between the sender ${ }^{1}$ and the target. If economic sanctions are only short-term and not used again, their impact may be limited. However, if they are frequently used, firms engaged in economic activities in both countries may eventually decide to exit this particular pair of countries, for fear of economic disruption. In this way, economic interdependence between conflict-prone countries can be driven to low levels over a sustained period of time.

Discussions about long-term consequences relate to an important consideration of the relationship between diplomacy and economics. It is mostly private economic actors - such as firms, investors, and individuals - who are engaged in day-to-day economic activities, and not the state (except for state-owned industries, which may behave differently from private actors). Therefore, their expectations regarding the political relationship between the concerned countries directly impact the level of economic interdependence between the countries. China-plus-one can be understood within this context, and it may occur somewhat independent of the actual conflict between Japan and China. Even in the absence of actual clashes between the two countries, private economic actors may adopt this strategy if they foresee actual conflicts in the near future.

The international relations literature has thus far paid relatively little attention to private actors' responses to international crises or political tensions between countries. The "trade-follows-the-flag" hypothesis - the idea that trade declines in times of conflict -is tested on the aggregate level so that it is not clear whether this "economic" response to diplomatic relations is done by states or private actors (Pollins 1989a, 1989b). As a result, there is little theoretical basis to guide empirical research, and so the case study approach is useful in exploratory research. For this reason, I conduct a case study of the China-plus-one strategy, which has been adopted by Japanese multinational corporations since the $2000 \mathrm{~s}$. I then try to infer how corporations cope with political tensions between nations, and look to develop hypotheses for use in future research.

\footnotetext{
${ }^{1}$ In the economic sanctions literature, the state that imposes sanctions is called a "sender."
} 


\section{PREVIOUS RESEARCH ON FOREIGN DIRECT INVESTMENT AND POLITICAL RISK}

Also, in light of prior work on the relationship between political risk and FDI, massive inflows of FDI to China can be considered anomalous. First of all, it is considered that political risk in China is rated as being relatively high. For instance, among the 16 developing countries they rated, Delios and Henisz (2000) give the highest score of political hazard to China.

Prior work has established that various political risks affect FDI flows to emerging economies. Gastanaga et al. (1998), for example, determined that corruption and nationalization risks reduce FDI flows. Similarly, Wei (2000) found that corruption impedes FDI, and Kolstad and Tøndel (2002) show that FDI is affected by ethnic tensions and internal conflict. Busse and Hefeker (2007) found that governmental stability, internal and external conflict, government accountability, and the quality of bureaucracy determine FDI flows. Hayakawa et al. (2013) show that political risks are much more significant determinants of FDI than are financial risks. China does not fare well in terms of these political risk factors (e.g., corruption).

Another enigma in terms of political risk is that China is the largest recipient of FDI, despite the fact that it is not a democracy. Many studies (Harms and Ursprung 2002; Busse 2004; Busse and Hefeker 2007; Jensen 2008) have found that democracy mitigates policy uncertainty and tends to exert a positive influence on FDI flows.

How firms actually cope with political risk is another area of research that has remained relatively unexplored. FDI insurance - such as that offered by the United States Overseas Private Investment Corporation - covers only extreme cases of political risk. Third-party investment arbitration is another possibility, but the literature agrees that it is a last-resort option (e.g., Jensen 2008). Kobrin (1979) suggests such strategies as the purchase of information and the use of insurance and hedging.

The cases explored later in this paper show that insurance is certainly a preferred way of mitigating certain kinds of political risk, if not the entire gamut thereof. Finally, China-plus-one may be a new way of "hedging" that has been thus far unexplored.

\section{WHAT IS CHINA-PLUS-ONE?}

"China-plus-one" refers to a Japanese corporate diversification strategy. In the face of risk, portfolio diversification (to include an appropriate variety of stocks 
in one's investment portfolio) is known to be an optimal strategy for investors, and one that is well established in finance (Markowitz 1952). The same principle applies to corporations. Corporations, in the face of various business risks, can either diversify their product lines or alternatively diversify internationally by investing in an appropriate set of foreign countries (Madura and Whyte 1990). The China-plus-one strategy concerns a simple application of international diversification by Japanese multinational firms.

As the risk inherent in concentrating business transactions in China increased in the mid-200os, Japanese firms operating in China began to consider alternative investment locations. There are two types of alternative locations: low-wage countries in Asia, and other Association of Southeast Asian Countries (ASEAN) countries. The first group of countries includes Bangladesh, Cambodia, Laos, Myanmar, and Vietnam, where the prevailing wages are much lower than those in China. These locations are attractive to industries whose competitive advantages hinge largely on labor costs, such as apparel and consumer goods industries. The second group of countries includes Indonesia, Thailand, and Malaysia. Although their labor costs are comparable to or even higher than those in China, these locations offer high-quality skilled labor as well as good infrastructure; hence, they are attractive to such industries as electric appliance and general machinery manufacturers who maintain production centers in China for Chinese consumers, but are beginning to transfer other output away from China (Nakata 2012). Another option for Japanese firms concerned about China-related risk is to return operations to Japan. It is unclear from the literature whether this option is considered part of the China-plus-one strategy, but it certainly constitutes another form of diversification.

Additionally, a think-tank report points out that small and medium enterprises are more likely to adopt the China-plus-one strategy than are large corporations (Sako 2013). As evidence, that report cites August 2013 survey data, where-

in 70 percent of large Japanese firms reported that they would not reduce their capital investment in China.

\section{TRENDS IN JAPANESE FOREIGN DIRECT INVESTMENT}

Japanese FDI boomed in the wake of the Plaza Agreement of 1985. After a sharp appreciation in the yen, Japanese export industries lost their competitiveness, and began to seek export platforms abroad. Initially, Southeast Asia was a favorite destination for Japanese FDI, but as Chinese liberalization accelerated in the 1990s, China topped the list for an extended period. 
Japanese FDI in China came in three major waves. ${ }^{2}$ The first wave came in the mid-1980s, following China's reforms and its moves to economically open up. These investors were primarily in light industries such as textiles. The second wave came in the early 1990s, when electric and electronics manufacturers began entering China. Investment in China dipped for a while in the wake of the Asian financial crisis in 1997-1998, but FDI in China recovered in the early 2000s, coinciding with China's accession to the WTO. This third wave was characterized by large-scale investments by financial institutions and auto manufacturers, which peaked in 2005. The investment environment in China changed dramatically after the Beijing Olympic and Paralympic Games of 2008 and until 2009, when the government changed its preferential tax treatments for foreign multinationals and introduced new labor laws to protect workers' rights. As a result of these changes, Japanese firms in labor-intensive sectors began to shift their operations elsewhere.

Figure 1. Japanese Net FDI Flows to China (1987-2014)

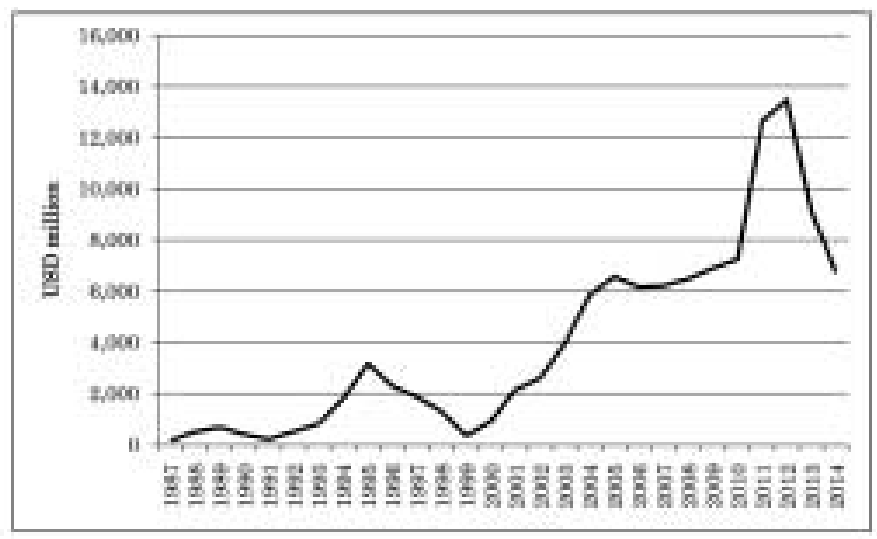

Source: Japan External Trade Organization (JETRO).

Since reaching its peak in 2005, the amount of Japanese FDI in China has alternated between highs and lows. Following the anti-Japanese protests in the spring of 2005, Japanese FDI dropped, and investments made in 2006 were lower than those in the previous year. In 2007, the total amount of Japanese FDI in Southeast Asia surpassed that in China. The aforementioned regulatory changes in the late 2000s reduced FDI further still. However, despite there being height-

${ }^{2}$ The information in this paragraph derives from an article in Nikkei: Nihon Keizai Shimbun (Nikkei hereafter), p. 15 (January 14, 2012). 
ened tensions in Sino - Japanese relations in 2010, the amount of Japanese FDI in China recovered in 2011. The next year, flows to China further climbed and amounted to almost twice the amount of the record low, seen in 2007 (Nikkei June 24, 2013, 19). By that time, 25,000 Japanese firms had made FDI in China (Nikkei June 24, 2013, 19). FDI flows to China have again dropped since 2013. According to Chinese statistics, Japanese FDI saw a 38.8 percent drop in 2014 from the year before (Nikkei January 17, 2015, 7).

In contrast, investment in Southeast Asia has been persistently strong. According to the Japan External Trade Organization (JETRO), between 2009 and 2012, net FDI flows to ASEAN nations from Japan surpassed those to China (Nikkei March 11, 2013, 25), in a net amount of JPY1.15 trillion. This happened partly because of strong economic growth in the region. This enthusiasm for investment in Southeast Asia is reflected in the data collected through various surveys. For example, En Japan - an internet recruitment company - asked Japanese workers who wished to work abroad about their preferred destination; one in three respondents said he or she wanted to work in Southeast Asia. 3

Since Japanese FDI flows to China have vacillated widely in recent years, it is difficult to foresee or extrapolate any definite trend. One thing that can be said with a fair amount of confidence is that steady investment flows from Japan to China are no longer assured. Figure 2 shows an indicator of the China-plus-one phenomenon. For this indicator, the amount of Japanese net FDI flows to China is divided by the total FDI flows to ASEAN countries, India, and Bangladesh combined. This index value has been in steady decline since 2012.4 The sudden upswing in the first half of 2012 is not due to an increase in FDI flows to China, but rather to a sudden dip in FDI flows to South and Southeast Asian nations.

\footnotetext{
${ }^{3}$ In the same survey in 2010, East Asia (China, South Korea, and Taiwan) was the most frequently cited destination. Nikkei, p. 9 (October 22, 2013).

${ }^{4}$ However, one should be careful in interpreting the pattern of behavior evidenced in Figure 2. The China-plus-one phenomena as measured in Figure 2 could arise from either of the following two causal mechanisms: one is that each and every firm is indeed applying the principle of portfolio diversification in their investment decision (although it makes sense, my interviews seem to indicate that this is not always the case); the other is that increasing risks in China are inhibiting one set of Japanese firms from making fresh investments in China, while another set of firms are increasing their investments in Southeast Asia because of economic stagnation at home. These two sets of companies may be different, but at the aggregate level, we may observe the same pattern as in Figure 2.
} 
Figure 2. China-Plus-One: Net FDI Flows to China/Net FDI Flows to ASEAN, India, and Bangladesh, All Industries (2011-2014)

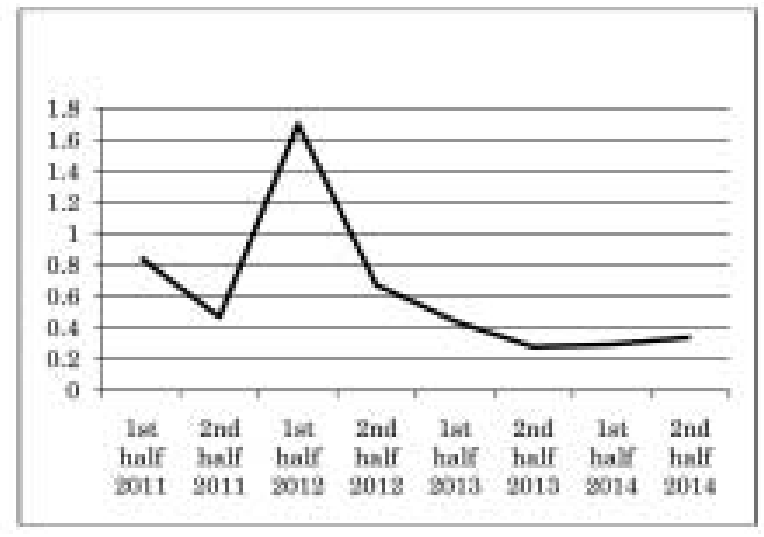

Source: Bank of Japan.

\section{CHINA RISKS}

What are the "China risks" that drive Japanese multinationals to look elsewhere for investment targets? Different analysts refer to somewhat different sets of risks. According to Fujita and Hamaguchi (2006), the biggest risk is labor shortages, followed by the revaluation in July 2005 of the Chinese renminbi. Security risks have included the outbreak of the severe acute respiratory syndrome (SARS) epidemic in 2003, and anti-Japanese protests in 2005. They also mention energy shortages and institutional uncertainty (e.g., "leaks" of technological information). More recently, Nakahara (2013) has added risks related to the burst of the property bubble, increased labor strife, the added costs of coping with environmental problems, and the risk of large-scale riots by farmers and other individuals.

Recent years have also seen an increase in external risks. Nakata states that "there are ever-present political and territorial strains that are cause for businesses to hedge their bets" (2012). The biggest shock to Japanese investment in China occurred after the Noda government nationalized the Senkaku Islands, in the form of ensuing anti-Japanese protests in September 2012. Thus, in October 2012, Japanese FDI in China fell to JPY63.4 billion, down almost 30 percent from the previous year (Nakata 2012).

In the following, we discuss various risks inherent in investment in China, starting with nonpolitical risks followed by political risks. These different factors are discussed in chronological order although at times, several factors were concur- 
rent. The first impetus for China-plus-one was a SARS epidemic.

\section{SEVERE ACUTE RESPIRATORY SYNDROME (SARS) EPIDEMIC}

Japanese multinational manufacturing firms in Malaysia began to use the phrase "China-plus-one" in 2003, following the SARS epidemic in China. According to Nihon Keizai Shimbun (Nikkei), the phrase referred to the necessity of having at least one other production center in the East Asia region that was outside of China (Nikkei October 31, 2003, 8). This new trend resulted in the reversal and recovery of investment flows to Southeast Asia in 2003. Thailand in particular attracted Japanese investors in 2003, with FDI flows more than doubling from the previous year. FDI flows to Malaysia also increased (Nikkei December 25, 2003, 8).

\section{LABOR SHORTAGES, COSTS, AND UNREST}

Although the SARS epidemic provided the initial impetus for the China-plus-one strategy, a consistent driver of Japanese firms away from China has been the rise of labor costs due to an increasingly severe shortage of labor, especially in urban areas. Labor unrest - wherein workers have demanded wage increases - became more prevalent in China in the 2000s; the labor strikes in the spring of 2010 were especially significant. A new labor regulation came into effect in 2008 that gave the assurance of lifetime employment to workers who worked for the same company for 10 consecutive years. Although the Chinese government tried to pacify foreign investors, this certainly drove wage increases. In addition, the legal minimum wage was continually raised in both Guangdong Province and the Huadong region. In the 10-year period from 2001 to 2010, urban wages in China increased at an average rate of 15 percent per annum (Nikkei March 17, 2012, 9).

The renminbi's appreciation since 2007 has also significantly increased the cost of doing business in China, as the Chinese government decided to revalue the Chinese renminbi against the US dollar. In 2007 alone, the renminbi appreciated by 7 percent against the dollar, and that trend continued thereafter (Nikkei Sangyo Shimbun March 6, 2008, 22). To the extent that Japanese firms were using China as a platform for exports to third countries, the renminbi appreciation added considerably to their costs of production.

In addition to rising costs, China's labor supply itself has grown uncertain. For example, in the spring of 2010, a large proportion of workers who returned home to celebrate the lunar New Year holiday never returned to their workplace. The reason seemed to be an increase in employment opportunities in rural areas (Nikkei Sangyo Shimbun, October 22, 2010, 22). Because of this incident, apparel makers could not supply their products for the new season on time.

It should be noted, however, that wages in alternative host countries also con- 
tinued to rise in the 200os and thereafter. For example, Vietnam — which suffered from a high rate of inflation - increased its minimum wages twice in 2011 alone. Thailand also raised minimum wages in 2011, in spite of the damage sustained from floods in the previous year. Cambodia, Laos, and Myanmar, each of which began to attract a number of foreign investors in the textile sector, saw wage levels increase by 10 percent per year in the early 2010 s (Nikkei March 17, 2012, 9).

\section{CHINESE POLICY MEASURES}

Another factor driving FDI away from China was the introduction there of a series of government policy measures related to FDI. For instance, in 2006, the Chinese government began to introduce measures that were purported to suppress exports, such as reduced preferential tax treatment for export product assembly operations. Another motive behind such measures was the Chinese ambition to upgrade their industry structure from simple assembly operations to high-tech industries, as well as an intention to reduce energy and other resource use (Nikkei August 17, 2007, 11). As a result, Japanese FDI flows dipped by 24.3 percent from January to October in 2007, compared to the previous year (Nikkei November 26, 2007, 6).

\section{POLITICAL RISKS}

This study considers that one of the most important "China risks" is political. However, the nature of political risks varies from incident to incident, making it difficult for Japanese multinationals to guard against the next crisis. The massive anti-Japanese protests in the spring of 2005 alerted the Japanese managers of multinationals to China's political risks. However, these risks were mitigated and subdued by Prime Minister Abe's visit to China in October 2006. The next crisis came in September 2010, when a Chinese fishing boat collided with a Japanese Coast Guard vessel; as mentioned, this incident sharply increased political tensions between China and Japan, for about one month. However, in terms of impact, no incident tops the 2012 crisis triggered by the nationalization of the Senkaku (Diaoyu) Islands in September of that year.

The precise reason for the massive anti-Japanese protests throughout China in April 2005 is still shrouded in mystery. On April 2, the first massive antiJapanese demonstration took place in Chengdu, to protest the Japanese bid for a permanent seat at the United Nations Security Council. Itoyokado, a Japanese department store, had several window panes broken by protesters, and the local police arrested several perpetrators of vandalism. The protests then quickly spread to the rest of the country, first to Shenzhen, and then to at least 12 other major cities. The Japanese embassy in Beijing was attacked on April 9 by pro- 
testers throwing pebbles, and warnings were issued to 74,000 Japanese nationals residing in China to stay home. On April 16, tens of thousands of people participated in anti-Japanese demonstrations in Shanghai, and the Japanese consulate building was again damaged. To contain the spread of protests, the Chinese government shut down "patriotic" websites that called on people to participate in protests against Japan. The Chinese law enforcement authorities also arrested people who were suspected of having masterminded these protests.

Deputy Foreign Minister Ichiro Aizawa visited China and met with Chinese Foreign Minister Li Zhaoxing on May 10; the latter promised that the Chinese government would try to restore the Japanese embassy and consulate buildings that were damaged during the protests (Asahi Shimbun May 11, 2005, 3).

While this 2005 incident was relatively small-scale and short-term, it was enough to scare away some Japanese multinationals. Teikoku Databank surveyed the Japanese firms that had been planning to begin operations in China; of 848 companies, 275 (32.4 percent) said that they would delay the start of their Chinese operations (Asahi Shimbun May 12, 2005, 3).

This new trend could be observed at the firm level as well. During the antiJapanese protests, workers at Uniden Corporation, a manufacturer of telecommunications equipment, went on strike. Afterwards, Uniden announced plans to open a second manufacturing site in Asia, outside of China; until then, they had manufacturing operations only in China (Asahi Shimbun May 26, 2005, 13). This was the first sign of an emerging China-plus-one strategy triggered by antiJapanese protests in China.

The 2010 crisis came in a different form. On September 7, 2010, a Chinese fishing boat collided with a Japanese Coast Guard vessel that was patrolling off the coast of the Senkaku Islands. The Japanese authorities arrested the ship captain on criminal charges. Upon seeing that Japan was serious about indicting the captain, the Chinese government vigorously protested, summoning the Japanese ambassador every day for questioning. China also resorted to a series of retaliatory measures, including the suspension of exports of rare earths - a resource essential to industrial applications in Japan. The Naoto Kan government relented in the face of Chinese pressure, releasing the ship captain on September 25, 2010.

The Chinese authorities, however, prevented large-scale anti-Japanese protests on the anniversary of the Japanese invasion of China, on September 18, 2010. By blocking the roads surrounding the Japanese embassy the night before, the Chinese authorities were able to contain the protests to approximately 100 people. However, after the crisis subsided, larger-scale anti-Japanese protests took place in three cities on October 16-18. In Chengdu on October 16, thousands of protesters gathered outside the Itoyokado and Isetan department stores, throw- 
ing rocks and plastic bottles (Asahi Shimbun October 17, 2010, 1). On October 17, some 10,000 protesters gathered in Mianyang, Sichuan, and attacked several stores that carried Japanese products (Asahi Shimbun October 22, 2010, 3). Overall, compared to previous protests, the damage to Japanese firms in China were much smaller during this crisis; nonetheless, the fear of ever-larger protests and of strains in political relations between the two countries pushed some Japanese firms to rethink their business model. Toray Industries said that it would reduce the production in China of a popular product, and shift its operations elsewhere (Asahi Shimbun October 23, 2010, 12).

The next crisis was much larger; additionally, its impact was deeper and its legacy longer-lasting. The September 2012 crisis was preceded by a mini-crisis in the previous month. On August 15, 2012, activists from Hong Kong landed on Uotsurijima Island, one of the Senkaku Islands; they and seven others aboard the ship were immediately arrested and deported two days later. In protest, antiJapanese demonstrations took place in at least 23 cities in China, including Hong Kong, on August 19. The Chinese police tried to contain the violence, but in Shenzhen, a Japanese restaurant was attacked. A week later, another bout of antiJapanese protests took place in two cities. On August 27, 2012, the limousine carrying Japanese Ambassador Uichiro Niwa was stopped on the street in Beijing, and its Japanese flag was stolen. However, this mini-crisis was a mere precursor of what was to come.

The Yoshihiko Noda administration - which had been debating what to do with the Tokyo Municipal government's plan to purchase the Senkaku Islands from the landowners - decided to nationalize the islands; to that end, it signed an agreement with the landowners on September 3, 2012. Formal nationalization procedures were completed on September 11, 2012. The internet in China was soon filled with calls for anti-Japanese protests and boycotts of Japanese products, leading to massive anti-Japanese protests in more than 100 cities on September 15-18. The Chinese authorities half-heartedly tried to contain the violence, but vandalism against Japanese factories, retail stores, and dining establishments took place everywhere. In Qingdao, arsonists attacked a Panasonic factory and a Toyota car dealership. In Changsha, Hunan Province, demonstrators broke into a Japanese-owned department store (Heiwado) and damaged windows and products. They also set fire to the building materials in front of the store. In response, most Japanese factories and retail chains temporarily shut down, until order was restored. This wave of protests was contained only after September 19, when Chinese authorities decided to ban them altogether.

Japanese businesses suffered massive damage. For example, Heiwado said that its losses totaled JPY5O0 million, from damage to three outlets in Hunan 
Province. Later, the Japanese government estimated the total damages from the anti-Japanese demonstrations in China to range from billions to tens of billions of yen (Asahi Shimbun November 13, 2012, 1). Japanese automakers saw both the production and sales of Japanese cars in China decline precipitously after the crisis. In October 2012, exports of Japanese passenger cars to China fell by 82 percent from the same month of the previous year (Asahi Shimbun November 22, $2012,8)$. Toyota announced reductions in the local production of cars in China by 20 percent, from November until the end of the year (Asahi Shimbun October 18, 2012, 1).

Paradoxically, many Japanese retail chains were bullish on business prospects in China. Uniqlo opened 12 new retail stores in China in September, as planned: the company - which had planned to open 80 new retail outlets in China by August 2013 - said that it would not change its original plan (Asahi Shimbun October 28, 2012, 1). Heiwado reopened stores one month earlier than scheduled. Nissan, for which China accounts for one-quarter of its worldwide sales, had been constructing a new plant in Dalian, and completed it on schedule (Asahi Shimbun November 10, 2012, 3).

On the other hand, Watami, a Japanese casual dining chain that had planned to open 40 new establishments in China, decided to reduce that number byonehalf (Nikkei November 7, 2012, 3). In a November 2012 survey executed by Teikoku Databank, it was found that " 1 out of 6 Japanese companies said they were looking to scale down or shut down their China operations," and that " 15.5 percent of [respondents] said they were considering withdrawing from China or scaling back business there" (Nakata 2012). It was only after the end of 2012 that Japanese FDI flows began to decline.

\section{RELATIVE IMPACT OF POLITICAL RISKS}

What is the relative significance of various risks that relate to investment in China? According to a survey conducted in August 2013, among the respondents who intended to reduce capital investment in China, more than twice the number of respondents cited factors not related to Sino-Japanese relations than those who did cite a deterioration in Sino-Japanese relations (Sako 2013). Thus, it seems that the impact of political risks is smaller than that of economic motives.

On the other hand, the impact of political risk seems to be on the rise. For example, after each of the 2005, 2010, and 2012 anti-Japanese protests, the Japan Bank for International Cooperation (JBIC) asked Japanese firms operating in China to assess the impact of these protests on their business. While the proportion of Japanese firms reporting grave or even some negative impacts was 10 percent in 2005, this figure increased to 22.6 percent in 2010 and 65.1 percent in 
2012 (Table 1).

Table 1. Impacts of Political Crises

\begin{tabular}{l|l|l|l|r}
\hline \multicolumn{2}{|c|}{} & $\begin{array}{l}\text { Negative impact of } \\
\text { 2005 anti-Japanese } \\
\text { protests on business } \\
\text { activities (\%) }\end{array}$ & $\begin{array}{l}\text { Negative impact of } \\
\text { 2010 anti-Japanese } \\
\text { protests on business } \\
\text { in China (\%) }\end{array}$ & $\begin{array}{l}\text { Negative impact of } \\
\text { 2012 anti-Japanese } \\
\text { protests on business } \\
\text { in China (\%) }\end{array}$ \\
\hline \multirow{2}{*}{ Responses } & Grave impact & 1 & 3.4 & 22.3 \\
\cline { 2 - 5 } & Some impact & 9 & 19.2 & 42.8 \\
\cline { 2 - 5 } & No impact & 77 & 59.6 & 20.8 \\
\cline { 2 - 5 } & Unclear/Don't know & 13 & 17.8 & 14.1 \\
\hline Respondents & 557 firms & 416 firms & 327 firms \\
\hline
\end{tabular}

Source: Japan Bank for International Cooperation (JBIC).

Another glimpse into the relative impact of political risks on Japanese business can be obtained by examining the answers to another survey question regularly asked by the JBIC. The survey asks Japanese firms operating in China to select from a list as many choices as applicable of those problems they experienced in their business in China. In recent years, the increase in labor costs has topped the list, but an increasing number of Japanese firms point to security and social unrest as serious problems. In 2005 and 2013 - in the wake of the 2012 crisis more than 30 percent of respondents chose "security/social unrest" as problems in China (Figure 3).

Figure 3. Problems Associated with Doing Business in China (2003-2014)

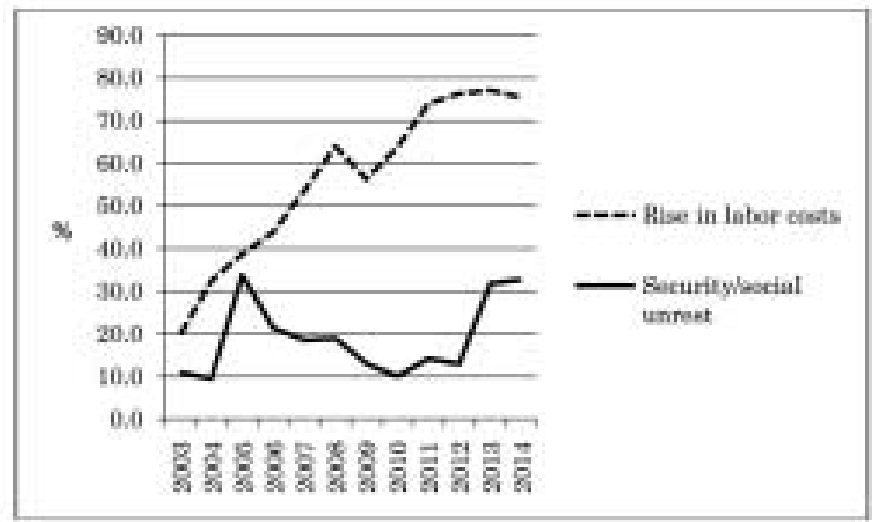

Source: Japan Bank for International Cooperation (JBIC). 
The impact of political risks is uneven, depending on the type of business that Japanese multinationals are engaged in. For example, increases in labor costs have impacted labor-intensive industries most, especially the textile sector; thus, with increases in labor costs in China, the textile industry could steadily migrate to other countries. Each time they have occurred, anti-Japanese riots have impacted the retail and dining industries - both of which are labor-intensivemost, compared to all other industries. Finally, the Japanese auto industry suffered considerably, especially on account of a consumer boycott that occurred during and after the September 2012 crisis. Figures 4-6 support the hypothesis that these three sectors have shown a steady and considerable application of the China-plus-one strategy.

Figure 4. China-Plus-One: Textile Sector (2011-2014)

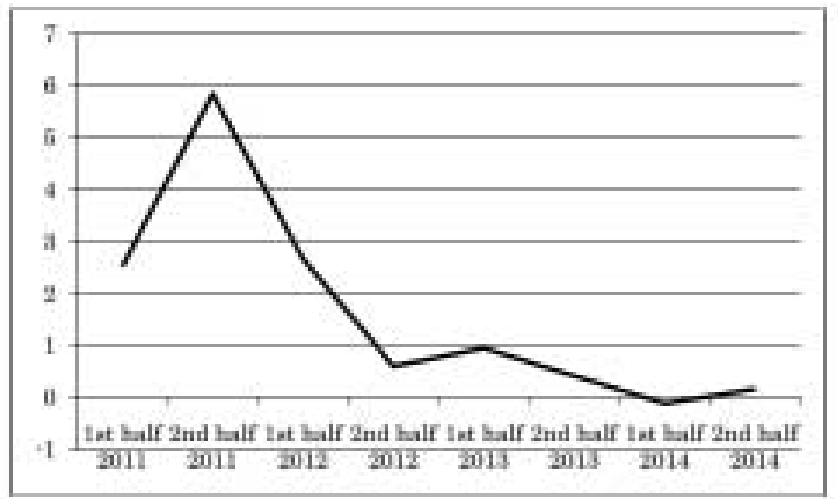

Source: Bank of Japan.

Figure 5. China-Plus-One: Wholesale and Retail Sectors (2011-2014)

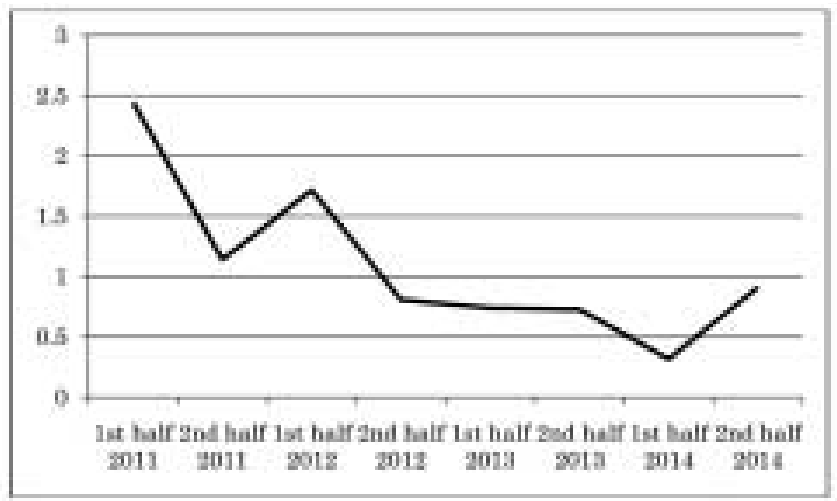

Source: Bank of Japan. 
Figure 6. China-Plus-One: Transportation Machinery Sector (2011-2014)

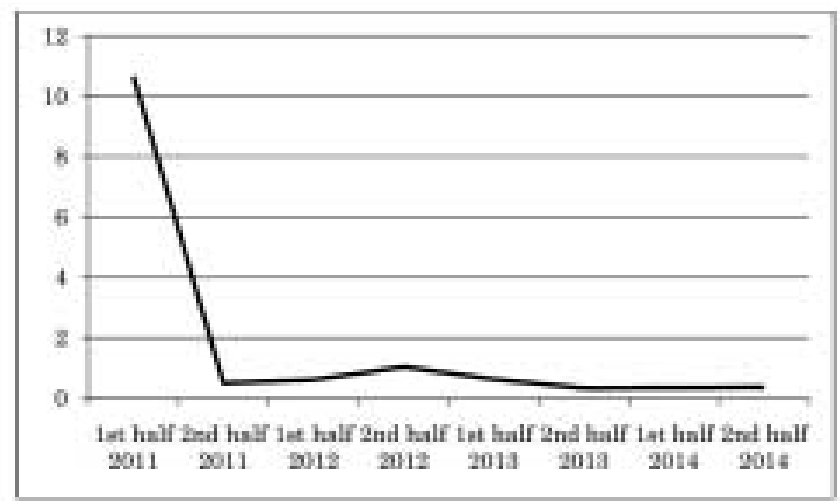

Source: Bank of Japan.

This subsection has described political risks in China faced by Japanese corporations and examined the degree to which China-plus-one is progressing in the three sectors that were supposedly impacted by China risks: textiles (because of rising costs), the auto industry (because of consumer boycotts) and retail (because of vandalism in successive anti-Japanese protests). Unfortunately, the data on this analysis are not as revealing as I had hoped because the data are aggregated at a larger level than warranted (namely, autos are combined with other transport machines and retail is combined with wholesale).

\section{"PLUS-ONE" COUNTRIES}

\section{THAILAND}

Thailand is by far the most favorite FDI destination for Japanese multinationals, in terms of their China-plus-one strategy. Industry clusters consisting of Japanese and local joint ventures are well established in several locations. Flooding in the metropolitan region in 2011 depressed Japanese investment, but there was a quick recovery afterwards. Japanese FDI in Thailand surpassed that in China in 2013 (Asahi Shimbun December 20, 2014, 22).

According to Teikoku Databank, among the Japanese firms operating in two foreign countries, the most frequently observed country pairing was China plus Thailand (Seki 2013). In addition, a survey conducted by Nihon Seisaku Kinyu Koko (Japan Finance Corporation (JFC)) in the summer of 2013 showed that China and Thailand were, for the first time, equally positioned by Japanese cor- 
porations as the most promising FDI destination. Until this time, China had dominated the list (JFC 2013).

For example, while Japan's injection molding machinery industry saw exports to China and Hong Kong in 2012 drop by 15 percent in yen terms, injection press exports to the largest market, Thailand, nearly doubled. In 2012, Thailand supplanted China as the top destination for Japanese molding machines (Toloken 2013).

However, political risks in Thailand are also a concern. The political situation in Thailand has been unstable since Prime Minister Thaksin Shinawatra was ousted by a military coup in 2006. The first civilian government after the coup under Prime Minister Samak Sundaravej ordered a curfew in Bangkok in September 2008, but union workers continued with strike action and occupied the Prime Minister's residence. Under Yingluck Shinawatra's government, both anti-government and pro-government forces demonstrated repeatedly in metropolitan Bangkok, disrupting traffic and businesses. Finally, on May 22, 2014, the military stepped in again and restored order. In view of this unstable political situation, the Japanese media began to use the phrase "Thailand-plus-one".

\section{MYANMAR}

Myanmar contrasts with Thailand, in the sense that its political climate has improved remarkably in recent years, and become more conducive to FDI. After a long period of military rule, a civilian government was established in 2010, and President Thein Sein undertook reforms at a rapid pace. In the April 2012 by-election, Nobel Peace Prize laureate Aung San Suu Kyi won a seat in parliament, and the Japanese government decided to resume disbursements of official development assistance to Myanmar. In November 2012, U.S. President Barack Obama visited the country, and announced that the United States would lift economic sanctions. Myanmar also enacted a new law on foreign investment, paving the way for renewed inflows of foreign capital. Thus, Myanmar became the most recent FDI candidate in China-plus-one strategies (Nikkei December 25, 2012, 23). Total FDI inflows from April 2013 to March 2014 (in the amount of USD4.1 billion) are estimated as being three times higher than those in the previous year (Nikkei July 14, 2014, 1).

As of October 2012, 91 Japanese companies were operating in Myanmar, up by 75 percent from 2010 (Nakata 2012). Major firms doing business in Myanmar include Okaya \& Co., Kanematsu, and machinery maker Kubota. Additionally, Juroku Bank partnered with Ayeyarwady Bank "in the first such arrangement between a Japanese regional lender and a Myanmar financial institution" (Nakata 2012). Finally, Honeys - a Japanese women's clothing manufacturer- 
acquired a factory from an Indian company outside Yangon, and started operations in April 2012 (Nikkei June 13, 2012, 6).

The most attractive aspect of Myanmar is its low wages. As of October 2013, the monthly wages of workers at Japanese firms in Myanmar were USD71, compared to USD86 in Bangladesh, USD101 in Cambodia, and USD162 in Vietnam. However, it has also been reported more recently that the labor supply has grown short in the Yangon area (Murata 2014). Another advantage for Japanese firms is that Japan grants preferential treatment to imports from Myanmar, under the generalized system of preferences (GSP) program; this alone gives Myanmar products a 10-percent cost advantage compared to Chinese products (Nikkei February 26, 2013, 2). On the other hand, shipping textiles from Myanmar to Japan takes three to four weeks, in comparison to four to seven days from China; thus, Myanmar is not a suitable production base for products subject to brisk changes in fashion or trends (Nikkei November 15, 2012, 9).

\section{VIETNAM}

Vietnam had been attracting Japanese capital much earlier than Myanmar, with an FDI boom occurring between 1994 and 1996. In 2000, the business law was amended, and the resulting deregulation led to higher economic growth. From 2005 to 2008, economic growth exceeded 8 percent year-over-year, thus attracting FDI. Nihon Keizai Shimbun called this round of FDI flows the "second boom." (Nikkei February 10, 2008, 19) The Economist noted in 2010 that in Hanoi, there was "renewed talk of 'China-plus-one' as a strategy for multinationals keen to spread their bets." 5

As in other countries, Vietnam has had a cost advantage relative to China. Fujita and Hamaguchi (2006) argue that Vietnam is considered an alternative to Guangdong for investment, as the wages of unskilled labor in the latter locale have started to rise. However, this cost advantage is somewhat precarious, given constant pressures for wage increases. For instance, in 2008, the number of strikes in which workers demanded wage raises reached 726, up 34 percent from the year before (Nikkei Sangyo Shimbun January 21, 2009, 9). Recently, these strikes have also become more violent.

Compared to China or Thailand, political risks are much lower in Vietnam. However, after China began operating oil rigs in South China Sea waters claimed by both Vietnam and China, anti-Chinese protests raged in Vietnam. In May 2014, a number of foreign companies suffered damage from anti-Chinese protests, because Vietnamese protesters mistook Taiwanese and Japanese com-

5 “Plus One Country,” The Economist, September 2, 2010. 
panies for Chinese ones. In the south (i.e., Binh Duong Province), where more than 20,000 people attacked over 400 companies, 25 of them were related to Japanese capital (Nikkei June 3, 2014, 9). Another concern among Japanese firms during that crisis was the possible disruption of supply chains between China and Vietnam. As part of their China-plus-one strategy, Japanese firms moved assembly operations to Vietnam - although manufacturers of materials and parts have not followed suit, leaving assembly operations dependent on input supplies from China (Nikkei June 3, 2014, 9). Some Japanese companies have even made contingency plans to airlift supplies in cases of border closure, but China abruptly stopped oil-rig operations in the South China Sea in mid-July, and so this scenario did not materialize (Nikkei Sangyo Shimbun August 27, 2014, 5).

\section{BANGLADESH}

Like Myanmar, Bangladesh is another newly rediscovered investment destination that serves as part of the China-plus-one strategy. Bangladesh, by leveraging its cheap labor, has become a major center for textile and apparel production. However, due to its distance from Japan, Japanese firms have long been hesitant to invest there.

In 2009, a children's clothing manufacturer, Maruhisa, was the first to establish a factory in Bangladesh (Nikkei May 26, 2009, 12). However, it was not until 2010 that Japanese firms focused on Bangladesh, when Fast Retailing, the company operating the Uniqlo retail clothing chain, invested in Bangladesh. By then, Bangladesh had become a major supplier of clothing to such brands as H\&M, ZARA, and Gap.

Like many other "plus one" FDI destinations, Bangladesh's advantage is found in its lower labor costs. Even in the capital of Dhaka, the average monthly wage in 2010 was less than USD 50. Furthermore, the Japanese Ministry of Finance changed GSP policies, such that Bangladesh textile products would enter Japan duty-free, irrespective of local content (Nikkei MJ February 9, 2011, 4). Consequently, Japanese investment in Bangladesh is heavily concentrated in textiles. According to JETRO, of 176 Japanese firms operating in the country, more than one-half of them are in the textile sector (Nikkei Sangyo Shimbun April 4, 2014, 4).

\section{THE ROLE OF THE JAPANESE GOVERNMENT}

The Japanese government does have a role in the evolution of the China-plus-one strategy, though it has not yet made its stance clear. The only government-relat- 
ed organization that has sent some signals in any case is JETRO.

In 2003 - when the phrase "China-plus-one" first came into currency - JETRO President Osamu Watanabe said that he recommended that Japanese companies adopt this strategy (Nikkei September 15, 2003, 1). Thus, in the early years, even as Japanese multinationals were still unconcerned about China-related risks, JETRO was forward-looking and suggesting next steps. Ten years later, however, JETRO's tone changed. Yoichi Maie, Director of JETRO's China and North Asia Division, said that "There is no market like China. China is advanced in terms of industry clustering, including upstream and downstream sectors, and firms are able to procure a high proportion of their inputs locally. Even with lower labor costs [outside of China], production costs will not go down if one cannot procure inputs locally"; when asked if Japanese companies should continue to invest in China, he replied, "unless they continue [to invest further in China], they will face a more difficult prospect in the future." (Nikkei September 28, 2013, 7) Thus, JETRO began cautioning Japanese firms against skittishness in the wake of the 2012 crisis in Sino-Japanese relations.

\section{CHINA-PLUS-ONE AT THE FIRM LEVEL}

We have seen that, overall and generally speaking, the China-plus-one phenomenon is proceeding slowly but steadily. Can we affirm that this same phenomenon is occurring at the micro or firm level? To answer this question, I identified some firms that are likely to be taking the China-plus-one strategy in one form or another, and conducted interviews with them, either in person or by telephone. Many firms refused to be interviewed, and even those few that allowed interviews preferred not to be identified. These conditions alone indicate just how sensitive this topic is; this sensitivity may be one of the reasons why this topic has remained unexplored in the literature thus far. The following is the summary of the results of this research.

The findings can be summarized in terms of two points. First, not many firms are self-consciously undertaking a China-plus-one strategy, although their behavior is more or less in line with the China-plus-one hypothesis. In this sense, China-plus-one is not so much a micro-level strategy as a macro-level phenomenon. Second, aside from China-plus-one, many firms are aware of various risks inherent in investing in China, and they are taking risk-specific measures to deal with them. One of the most notable examples of dealing with political risk - such as possible losses from anti-Japanese demonstrations - is to strengthen ties with local governments in China. 
Company A, a producer of various industrial materials, has been investing in China since the early $1990{ }^{6}{ }^{6}$ Its first base in China was a city near Shanghai, but it later spread its operations elsewhere. One notable thing about this company is that it has a research and development center in China.

When asked about China-plus-one, the company representatives explained that their China-plus-one strategy is limited to one product area. The company provides textiles to another Japanese company, which in turn sews them into a very popular product. Before its diversification strategy was initiated, the percentage of textiles sewn into final products overseas (and outside China) was only 20 percent, but they want to increase that number to 50 percent by the end of 2015 .

Regarding other product areas, company $\mathrm{A}$ is committed to remaining in and continuing to produce in China. The representatives of company A say that even though economic growth is slowing in China, it remains one of the largest consumer markets, and it still has great potential as a market. Additionally, they say that the recent trend of emphasis on the environment gives the company a business opportunity, as it holds superior environmental technologies.

Company B, which runs a chain of Japanese-cuisine restaurants and pubs, has been investing in China since 2005.7 Prior to entering mainland China, it had had operations in Hong Kong; one of Hong Kong's developers opened shopping malls in Shenzhen and wanted company B to open a restaurant in that mall.

Company B opened franchise restaurants in the Philippines in 2012 and South Korea in 2013, so on the surface, it looks like they partake in a China-plus-one strategy, but it is not considered by the company as such.

The principal way in which company B mitigates China-related risk is to limit its number of outlets in mainland China. As the company representative explained, because China is governed by the Communist Party, if all operations were to collapse (e.g. due to expropriation), the damage would come to haunt the Japanese headquarters; this means that the Japanese headquarters must be able and prepared to withstand that shock.

Company $\mathrm{C}$ started investing in China for a special reason. ${ }^{8}$ The prefecture where it is headquartered had a friendship agreement with China's Hunan Province. On account of this relationship, it was invited to open a retail outlet, in a new shopping mall in the capital city. The company president - who had previously had no intention of investing in China - suddenly became eager after he vis-

\footnotetext{
6 The following is based on a not-for-attribution interview conducted on January 28, 2015.

7 The following is based on a not-for-attribution interview conducted on February 13, 2015.

8 The following is based on a not-for-attribution interview conducted on February 26, 2015.
} 
ited the city and saw how primitive retail business was in China. He thought that Japan's ways of retailing would help China develop.

Company $\mathrm{C}$ has not invested in any overseas location, save for China; in that sense, it is not engaged in a China-plus-one strategy. However, it is actively gathering information about some countries in Southeast Asia through financial institutions. Therefore, it could be said to be a would-be China-plus-one player.

The most notable strategy this firm is taking to mitigate China-related risk is to keep strong ties with the local government of Hunan Province. Like many other Japanese retail stores, this firm's outlets in Hunan fell prey to vandalism during the September 2012 anti-Japanese demonstrations. However, soon after that, the firm was reassured by the local government that it would provide maximum protection, so the firm decided to stay in China. At the time of the anti-Japanese protests in 2012, the company had plans to open a new outlet, and that has come to pass as planned.

Asked why it is difficult to reduce the size of its operations in China, the representatives of company $\mathrm{C}$ pointed to the morale of the Chinese company employees. In China, employee mobility is very high, and if employees hear rumors of a company scaling down its operations, they will lose hope of promotion inside the company and start looking for other employers that will offer promotions and better salaries. Therefore, it is common knowledge among Japanese companies that operate in China that they should be very cautious about making public pronouncements about divestment plans in China; it also explains companies' reticence in discussing the existence of a China-plus-one strategy at the firm level.

Company $\mathrm{D}$ is a manufacturing conglomerate, and its presence in China dates back to very early years. ${ }^{9}$ It was also a victim of vandalism in 2012, and some of its factories were heavily damaged by protestors.

Like many other companies, it realized that making strong ties with local governments is key to maintaining a risk-free environment in China, and so the company directed all managers in China to strengthen their ties with their respective local governments. However, one of the interviewees did say that while strong ties with local governments help them in terms of dealing with labor relations, it does not help as much in dealing with political risk.

Regarding insurance against riots, only a handful of company D's operation sites were covered by such insurance in 2012; after 2012, however, the company decided to purchase anti-riot insurance coverage for all of their production sites in China.

The interviewees all agreed that withdrawing from China is a very difficult

9 The following is based on a not-for-attribution interview conducted on April 23, 2015. 
process. When a factory closes, it is customary for workers to receive a premium, on top of their legally mandated severance pay. Negotiations over such premiums have sometimes led to labor strife. One of the interviewees recalled an episode in which the president of a local joint venture company was imprisoned in his executive office by the protesting workers outside, at the time of a factory closure.

As for the concept of China-plus-one, again, company D found the strategy difficult to execute. The company does not use China as an export platform, save for a small operation that exports to Europe. Most of company D's products made in China are sold in China, given the prohibitively high transportation costs that would be incurred if they were exported from other countries into China.

Another difficulty inherent in carrying out a China-plus-one strategy is the wellknown problem of restrictions vis-à-vis the repatriation of profits. It is difficult to repatriate profits from Chinese operations, and even at a time when company D was in financial difficulties, it could not take advantage of cash in China. However, the representatives of this company complained that there were fewer and fewer opportunities to reinvest cash inside China, largely due to rapidly increasing wage costs. Therefore, surplus cash that cannot be repatriated or reinvested simply accumulates in China. This phenomenon may be consistent with at least one aspect of China-plus-one: stagnating investment in China.

\section{AMERICAN FOREIGN DIRECT INVESTMENT IN CHINA}

Finally, it should be noted that the China-plus-one strategy is no longer limited to Japanese multinationals. Since 2008, relations between the United States and China have not experienced anything resembling Sino-Japanese tensions ${ }^{10}$; nonetheless, American companies are starting to adopt the China-plus-one strategy. This suggests that the China-plus-one strategy is primarily driven by economic factors.

U.S. firms in China have recently adopted this strategy. As early as 2008, a U.S. journalist noticed that "the beginning of what we shall dub the 'China-plus-one' strategy that is forming in the minds of American businessmen" (DevonshireEllis 2008). According to Devonshire-Ellis (2008), two factors have been driving this shift: economics and opportunity. The economics incentive derives from the increasing costs related to manufacturing in China, and that certain tax incentives have disappeared. The opportunity, on the other hand, lies in the fact that U.S.

${ }^{10}$ According to Weiss (2014), the last time massive anti-American protests happened in China was in 1999. 
executives perceive other markets in Asia as being ripe for expansion, to sell products locally. As Figure 7 shows, U.S. FDI inflows into China have been very volatile in recent years.

Figure 7. US FDI flows to China (1982-2014)

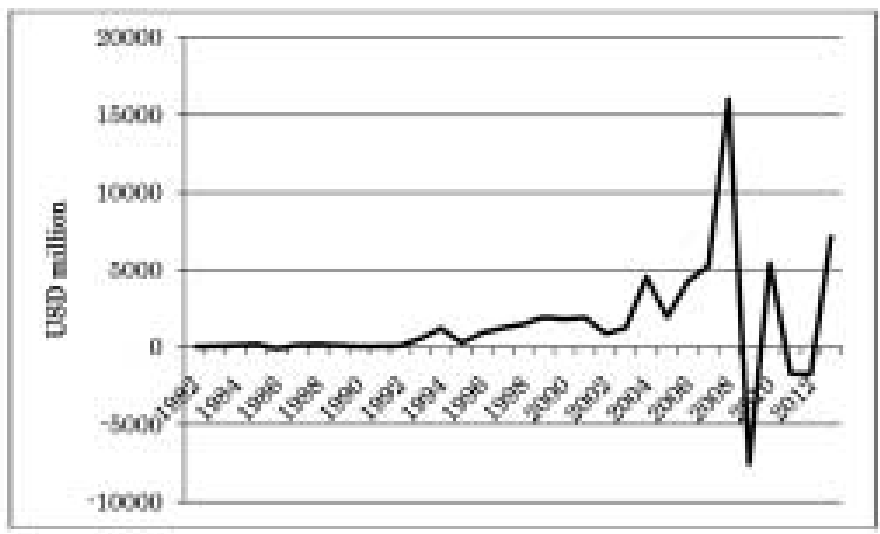

Source: Bureau of Economic Analysis (BEA).

\section{CONCLUSION}

This paper reported on a case study of the China-plus-one strategy that has been primarily adopted by Japanese multinational corporations. This case study offers several major findings. First, although FDI flows are subject to sharp short-term vacillations, the data show that there is a clear trend toward the prevalence of China-plus-one, as direct investment by Japanese firms in China, relative to that in "plus one" countries, is certainly in decline. Second, China-plus-one is first and foremost a strategy motivated by economic factors, such as labor costs; therefore, to the extent that the rate of increase in Chinese labor costs outstrips that seen in the "plus one" countries, the trend will continue. Third, in spite of previous findings that may state otherwise, there are signs that the China-plus-one strategy is also partially driven by risks engendered by political tensions between China and Japan. Anti-Japanese protests triggered by bilateral crises in 2005, 2010, and 2012 left tangible damage to Japanese assets in China, and the Japanese companies operating in China are now much more cautious about expanding their business in China. Fourth, and most importantly, there is an upward trend in the impact of political tensions on FDI in China. After each crisis, more companies 
are being affected by and have become more aware of political risk; thus, despite a temporary lull in the bilateral relationship due to the Asia-Pacific Economic Cooperation forum in Beijing in November 2014, the possibility of a recurrence in political tensions, followed by another major outbreak of anti-Japanese protests in China, cannot be ruled out. Fifth, Japanese corporations' preferred destinations for diversification are ASEAN countries such as Thailand, Vietnam, Myanmar, and Bangladesh. However, each of these countries has its own problems. Moreover, labor costs are also increasing in these countries, and the political problems in Thailand are considerable; these conditions imply that Japanese companies cannot escape risk altogether, regardless of where they invest.

\section{REFERENCES}

Baldwin, David Allen. 1985. Economic Statecraft. Princeton, New Jersey: Princeton University Press.

Busse, Matthias. 2004. "Transnational Corporations and Repression of Political Rights and Civil Liberties: An Empirical Analysis." Kyklos 57(1), 45-66.

Busse, Matthias, and Carsten Hefeker. 2007. "Political Risk, Institutions and Foreign Direct Investment." European Journal of Political Economy 23(2), 397-415.

Davis, Christina, Andreas Fuchs, and Kristina Johnson. 2014. "State Control and the Effects of Foreign Relations on Bilateral Trade." Mimeo (October). Accessed at http://papers.ssrn.com/sol3/papers.cfm?abstract_id=2519539 (May 29, 2015).

Davis, Christina L. and Sophie Meunier. 2011. "Business as Usual? Economic Responses to Political Tensions." American Journal of Political Science 55(3), 628-646.

Delios, Andrew, and Witold J. Henisz. 2000. "Japanese Firms' Investment Strategies in Emerging Economies." Academy of Management Journal 43(3), 305-323.

Devonshire-Ellis, Chris. 2008. "Corporate America's China Plus One Strategy." China Briefing (January 31). Accessed at http://www.chinabriefing.com/news/2008/01/31/corporate-americas-china-plus-onestrategy.html (August 18, 2015).

Fujita, Masahisa, and Nobuaki Hamaguchi. 2006. "The Coming Age of Chinaplus-one: The Japanese Perspective on East Asian Production Networks." Background paper for Dancing with Giants: China, India, and the Global Economy. Washington D.C.: World Bank. 
Gastanaga, Victor M., Jeffrey B. Nugent, and Bistra Pashamova. 1998. "Host Country Reforms and FDI Inflows: How Much Difference Do They Make?” World Development 26(7), 1299-1314.

Harms, Philipp, and Heinrich W. Ursprung. 2002. "Do Civil and Political Repression Really Boost Foreign Direct Investment?” Economic Inquiry 40(4), 651-663.

Hayakawa, Kazunobu, Fukunari Kimura, and Hyun-hoon Lee. 2013. "How Does Country Risk Matter for Foreign Direct Investment?” Developing Economies 51(1), 60-78.

Iida, Keisuke. 2013. "Trilateral Dialogue in Northeast Asia:A Case of Spill-over from Economic to Security Cooperation?” In T. J. Pempel ed., The Economy-Security Nexus in Northeast Asia, New York: Routledge, 164188.

Jensen, Nathan. 2008. "Political Risk, Democratic Institutions, and Foreign Direct Investment.” Journal of Politics 70(4), 1040-1052.

Kobrin, Stephen. 1979. "Political Risk: A Review and Reconsideration.” Journal of International Business Studies 10(1), 67-80.

Kolstad, Ivar, and Line Tøndel. 2002. "Social Development and Foreign Direct Investments in Developing Countries.” CMI Report 2002-11. Accessed at http://bora.cmi.no/dspace/bitstream/10202/194/1/Report\%20R\%202 o02-11.pdf (August 18, 2015).

Kumagai, Mitsumaru. 2013. Passing China: Nihon to Minami Azia ga Chokusetsu tsunagaru Jidai. Tokyo: Kodansha.

Madura, Jeff, and Ann Marie Whyte. 1990. "Diversification Benefits of Direct Foreign Investment.” MIR: Management International Review 30(1), 7385 .

Markowitz, Harry. 1952. "Portfolio Selection.” Journal of Finance 7(1), 77-91.

Murata, Motoo. 2014. "Myanmar in okeru Sen'i Sangyo no Genjo to Shoraisei." Asian Insight. Daiwa Soken Group. (January 16).

Nakahara, Keisuke. 2013. "China plus one ha mo furui: Korekaraha 'America plus one’ no Jidai.” Toyo Keizai Online (November 27). Accessed at http://toyokeizai.net/articles/print/25017(September 12, 2014).

Nakata, Hiroko. 2012. “Firms Move Some Eggs out of China Basket.” The Japan Times (December 19).

Nihon Seisaku Kinyu Koko (Japan Finance Corporation, JFC). 2013. "Chusho Kigyo no Kaigai Genchi Hojin no Gyokyo Chosa Kekka ni tuite.” (December 19).

Pempel, T.J. ed. 2013. The Economy-Security Nexus in Northeast Asia. New York: Routledge. 
Pollins, Brian M. 1989a. "Conflict, Cooperation, and Commerce: The Effect of International Political Interactions on Bilateral Trade Flows." American Journal of Political Science 33(3), 737-761. . 1989b. "Does Trade Still Follow the Flag?" American Political Science Review 83(2), 465-480.

Sako, Koji. 2013. "12-nen Kaki iko no Taichu/ASEAN Toshi: Kasoku shihajimeta Nihon Kigyo no China Plus One Senryaku.” Mizuho Sogo Kenkyusho (November 11).

Seki, Tomohiro. 2013. "Susumu China Plus One Keiko." Teikoku Databank (October 1).

Toloken, Steve. 2013. “'China-plus-one' Strategy Taking Root.” Plastic News (July 3). Accessed at http://www.plasticsnews.com/article/20130703/OPINIONo2/130709950/china-plus-one-strategy-taking-root(May 29, 2015)

Wei, Shang-Jin. 2000. "Local Corruption and Global Capital Flows." Brookings Papers on Economic Activity 31(2), 303-354.

Weiss, Jessica Chen. 2014. Powerful Patriots: Nationalist Protest in China's Foreign Relations. Oxford and New York: Oxford University Press. 